\title{
20 years Collaborative Governance and Action Research: Evaluation Process of the Regional Spatial Planning of Mappi Regency, Papua Doddy Aditya Iskandar*
}

Department of Architecture and Planning, Faculty of Engineering, Universitas Gadjah Mada, Indonesia

Submitted: May 31 2019 ; Revised: March 19 2021 ; Accepted: June $04^{\text {th }} 2021$

$\begin{array}{ll}\text { Keywords: } & \text { Abstract This paper evaluates planners' capacity to influence the plan- } \\ \text { Decision- } & \text { making process where it often involves actors and institutions with various } \\ \text { making } & \text { interests. Relegating planners' roles by providing mere technical inputs to } \\ \text { Spatial plan } & \text { those who seek advice would not alleviate spatial imbalance and the unequal } \\ \text { Review } & \text { power structure embedded in the community. Planners should be reflexive } \\ \text { Papua } & \text { and accountable, as it will lead them to aspire to a contested ideal rather than } \\ & \text { to simply optimize the current system where they are in. Drawing from our } \\ & \text { experience in reviewing the regional spatial planning of Mappi Regency, } \\ & \text { providing an alternative approach to current development strategies would } \\ & \text { help to balance the local community's power structure. Planners should } \\ & \text { master the politics of planning as it would help them influence the decision- } \\ & \text { making process. }\end{array}$

\section{INTRODUCTION}

The practice of community service requires a new set of approaches allowing greater participation from multiple actors and institutions, including local community members. As the practice of community service inherently belongs to the discipline of social work, several theories are dealing with how practitioners of community service view the local community and society interact one with another and how such an interaction informs these practitioners in devising a better approach to empower the community (Stukas \& Dunlap, 2008). Community service allows practitioners to collaborate with policymakers and local community members in devising a better strategy for development or revising policy and development approaches focusing on the sectoral, intersectoral, or spatial aspect of the development process.

As local government is impeded with fiscal impediments and mounting challenges, the idea of infusing community development and collaborative governance into the decision-making process and development attracts many local governments. Community development indicates a process where decision-makers allow room for participation from non-state actors to achieve the shared vision. Paradigm shift, which engulfed the governance of the development process both at a regional and local level, has forced scholars and practitioners to rethink and situate community development in a new context (Brenner et al., 2010; Geddes, 2010). The term and definition of 'community development', which is often described as a standalone service program operate alongside other social welfare service programs funded by the government, is rejected under the assumption that such an approach fails to recognize current challenges at the local level. In addition, local governments might not have adequate resources to successfully engage such a program to empower their local communities and those in need and marginalized.

Collaboration means working together with others to address or respond to a specific problem (Ansell \& Gash, 2008; Bentley et al., 2017; Voorn et

ISSN 2460-9447 (print), ISSN 2541-5883 (online)

${ }^{*}$ Corresponding author: Doddy Aditya Iskandar

Department of Architecture and Planning, Faculty of Engineering, Universitas Gadjah Mada, $2^{\text {nd }}$ Grafika Street, Sinduadi, Mlati, Sleman, Yogyakarta 55281, Indonesia

Email: doddy@ugm.ac.id 
al., 2019). As such, it calls for all participating stakeholders to focus their efforts through working with or through others, emphasizing participatory endeavor and the development of trust relations (Bentley et al., 2017; Voorn et al., 2019). Essentially, the principle of 'collaboration' stems from two competing paradigms, in which one paradigm focuses on the idea of market individualism that requires preferences and exchange and the other focuses on the aspect of community integration, which relies on shared preferences (Thomson \& Perry, 2006). Drawing from this perspective, collaboration entails a principle in which stakeholders will exchange resources and options to obtain their specific preferences, including central and local government (Leck \& Simon, 2013).

Governance concerns creative intervention by stakeholders to modify existing structures that inhibit the nature of the interaction between state and social actors and among social actors themselves (Ansell \& Gash, 2008). Governance reflects a different approach - as compared to 'government' -, which calls for greater participation and often through equal interaction from all involved actors to achieve shared goals (Johnston et al., 2011). However, most of the time, sharing goals requires actors to reconsider their needs and sacrifice some of their achievements. Actors will negotiate and make room for compromises where possible since each actor will measure their efforts against possible outcomes (Agranoff, 2006; Emerson et al., 2010; Emerson et al., 2011).

In adopting collaborative governance and community development in the plan-making process, one must consider challenges and constraints embedded in the process. As scholars pointed out the two distinct characterizations of power (Pansardi, 2012), power over, which indicates "the ability of A to exercise the power to $\mathrm{B}$ to the extent that $\mathrm{B}$ will do what A wants B to do something that B otherwise would not do", does not directly translate into the ability of power holders to channel his/her influence to other actors if their access to socio-economic and cultural resources are constrained by an external structure. Moreover, exerting will on others would result in disagreement of what kind of goals and objectives each actor should pursue. Rather than resorting to the imposition of individual power to other actors which shows a pattern of domination, scholars argue the merit of power over which signifies persuasion and empowerment to others (Dowding, 2008).

Collaborative governance and collaboration entail the need for working together to solve the problem. This argument requires each actor involved in the process to relinquish and share some of their power to achieve a common goal. The consensus that emerged from this deliberation process becomes the platform and social contract for all actors involved to pursue their objectives. However, achieving such a lofty goal was proven to be a difficult task for everyone involved. Surrendering and losing power would create the perception that not only A lost his/her ability to exert control to B to do something that B otherwise would not do, but also A lost his/her ability to do $\mathrm{x}$ on his/her account instead. As such, while power over is translated into social power, not all actors would be so easily made concessions to others to achieve the common goal. If actors do not easily relinquish their power (and access to socioeconomic and cultural resources), then how can they proceed to collaborate in the decision-making process? If planners (and planners-academics who exerted privileges and access to economic resources) were asked to get involved in the decision-making process, how can s/he utilize his/her skills and knowledge to influence the decision-making and balance the power structure among all actors involved?

These questions provide a framework to evaluate whether planners should relegate their position to merely technical advisors or play an aggressive stance by deploying an alternative narrative as a counterargument to the current development strategy in the decision-making process. Drawing from our experience in providing technical assistance and advice to review regional spatial plan for the government of Mappi Regency and USAID-Lestari, this article examines how recent theorizing conceives planners-academics engagement in the decisionmaking, including the planners' penchant to avoid politically sensitive approach and strategy, could lead to the development of counter-narrative to the current approaches. This empirical excursion results in an examination of planners' role within a wider context. As a result, we encourage planners-academics to embrace a realpolitik of development strategy.

The government of Indonesia requires each local government to create regional a spatial plan as guidance for the utilization of land and natural resources in its region. Despite the Law Number 26/2007 concerning Spatial Planning was established in 2007, local governments still feel unsure about how to best develop the plan as there was no incentive for the local community and private sector to follow rules and regulations of the utilization of private land. Market-based mechanisms still dictate (especially urban) land utilization and as a result, the local government had to develop a regional spatial plan to satisfy the requirement set forth by the central government.

The development process of regional spatial plans in Indonesia involves a mix of technocratic and political processes. Law Number 24/2007 concerning 113 Www.jurnal.ugm.ac.id/jpkm Vol. 7, No. 2, Indonesian Journal of Community Engagement 
spatial planning outlines steps to be taken to develop a regional spatial plan. The law stipulates that the spatial plan consists of spatial structure and spatial pattern with indicative programs to realize the spatial concept outlined in the structure and pattern of planned regional space. Moreover, the law also specifies the urgency for planners to construct functional relations between a regional spatial plan with a regional longterm development plan. The latter provides a framework for regional sectoral development to be detailed further in the regional medium-term development plan as a representation of the current head of a region (provincial and/or regent/district) or mayor of a municipality.

Planners-academics in Indonesia notes the discrepancy between what was stated in Law Number 24/2007 and the practice of drafting the regional spatial plan. As the Ministry of Home Affairs (MoHA) requires each region to develop a regional spatial plan as procedures for land allocation and utilization, including guidelines for attracting investment, local government often develops the plan with disregard to environmental impacts the plan might generate. This lack of environmental concern often stemmed from the need to increase locally owned revenue, one of the key performance indicators of the head of the region (governor, regent, or mayor).

The introduction of strategic environmental assessment (SEA) in 2009 as an integral element of the regional spatial plan allowed environmentalists to assess the impact of development from the realization of the regional spatial plan. As a result, spatial planners are tasked to evaluate possible development impacts to the environment and local community when they developed regional spatial plans. The incorporation of SEA into spatial plan making is seen as a strategy to minimize the unforeseen effect of various developments initiated from the regional spatial plans. Moreover, it was developed to address the spatial imbalance between risk-prone areas with high economic value areas. While the process is technically stringent, it is not devoid of political concerns from actors affected by the outcome. Several cases, such as the plan to build mine karst for cement factory in Kendeng mountain or border dispute between Blitar Regency and Kediri Regency, exhibited the inability of SEA to address environmental and social issues as the outputs of SEA were recommendations that could be ignored by policymaker(s).

Furthermore, the spatial plan-making process allows regional and local actors to bargain one with another to fulfill their interests. Law Number 23/2014 concerning local government stipulates various development rights and authorities embedded in the provincial, district, and municipal government. Moreover, the law also assigns each local government with specific tax rights. These often result in local competition between neighboring regions to attract investment and increase locally owned revenues. To minimize the negative impact of decentralization and devolution, the drafting process of the regional spatial plan calls for continuous consultation with the central government, especially the Ministry of Agrarian Affairs and Spatial Planning before being put forward as regional regulation (Bahasa Indonesia: Peraturan Daerah). The local government usually spent between 6 months and one year on average to consult and get approval from the central government. In most cases, the central government would mediate possible conflict between neighboring regions due to competition for natural resources or locally-owned revenues.

\section{METHODS}

The activity of reviewing and evaluating a local spatial plan of Mappi Regency took place since December 2017. Several experts were invited to collaborate to assist the local government of Mappi in evaluating their 2011-2030 local spatial planning and provide independent assessment on whether such a plan could be implemented without revision. Due to the local government's limited fiscal capacity, the plan for reviewing and evaluating Mappi's regional spatial plan was delayed until November 2018. The local government through its regional developmentplanning agency asked USAID-funded Lestari, a nongovernmental organization focusing on conserving tropical rainforest in three districts in the Province of Papua, to collaborate in financing the activity. In return, the government of Mappi was expected to incorporate Lestari's objectives (of conserving forest in Mappi) as one of their long-term development goals.

As such, this community service was designed to allow stakeholders and the local community to fully participate in the process. We approach this activity through the lens of action research, where we try to address both the theoretical gap and practical gap of decision-making in the planning and development field (Winter, 1993; Deemer, 2009). Utilizing action research in our case allows for interrogating how the current practice of planning and decision-making in the disadvantaged region like Mappi Regency is insufficient to provide greater room for local community members to fully participate and at the same time let us interrogate what would be the best approach to inducing collaborative governance in the development processes.

The collected data were initially sent from Mappi's local development planning agency and later 
Lestari's local staff added little information relevant to the evaluation process of the local spatial plan. Secondary data consisted of printed reports and legal documents (such as local regulations and technical reports on Mappi's spatial plan, and Mappi's mediumterm development plan). Primary data were collected through in-depth interviews and field observations, which took place in the fourth week of January 2019.

While the Ministry of Agrarian Affairs and Spatial Planning regulation set forth steps to conduct spatial planning review, experts developed specific approaches to incorporate local values into the assessment process. These resulted in the development of environmental, socio-economic, and infrastructure indicators that reflected what experts considered as important development aspects that should be considered in evaluating a regional spatial plan of the Mappi Regency. Specifically, as Lestari indicated their wish to incorporate their development goals of preserving tropical rainforest in Mappi into the document, two additional environmental indicators were called for the review and evaluation process of regional spatial planning of Mappi Regency:

Indicator number 2: Highly valuable conservation area and/or natural resources area (measured in hectare) under better natural resources management as a result of the USAID program, and

Indicator number 6: Number of strategic environmental assessment (SEA) recommendations related to land use planning, spatial planning, KEHATI forest management, and conservation used in the development process of local government policy, plan, and programs (including the regional spatial plan of Mappi Regency).

These two indicators reflect challenges in reviewing and evaluating the regional spatial planning document as the process of drafting the plan was entirely influenced by technical aspects set forth by the Ministry of Agrarian Affairs and Spatial Planning through several of its regulations and decrees. This process did not take into account environmental concerns from the perspective of other regional and local actors such as Lestari. Officials of the Lestari local office informed us that their stated indicators might not align with decision-makers focus on bolstering the local economy through infrastructure development to attract investment to the region.

Acknowledging and incorporating these challenges into the process of evaluating and reviewing the regional spatial plan led us to devise the following steps:

We identified local development issues and problems by juxtaposing Mappi's long-term and medium-term development plan (RPJPD and RPJMD) with Mappi's regional spatial plan. This would provide aims and directions for the development 115 www.jurnal.ugm.ac.id/jpkm and/or revision of the spatial concept of Mappi's regional spatial plan. Furthermore, the alignment between sectoral and spatial plan ensured that the outcome of regional development could be met within a designated period;

1. We developed open-ended criteria for evaluating the regional spatial plan. These criteria should be clear but flexible enough to accommodate various interests that the researchers (the community service team members) might encounter during the public hearing. The development of such criteria followed the principle of ex-ante evaluation;

2. We incorporated the abovementioned criteria with indicators outlined in the Ministry of Agrarian Affairs and Spatial Planning guidelines for reviewing the regional spatial plan. This would ensure that the outcome of the process would be easier to accept by regional and local actors, and

3. We triangulated the initial findings of the review process with a rapid assessment of the field. Since the local government and Lestari office only allocated five-day visit (including public hearing), a field visit was designed to capture the dynamics of the utilization of land and the local community's perception concerning the current state of regional development in Mappi and the vision of Mappi in the next ten to twenty years. The information would be sought through interviews with members of the local community, randomly selected to ensure the validity of the information.

Time limitation for field observation and the intent to influence the decision-making process led us to develop a specific strategy to present the researchers' ideas of what constituted a good regional spatial plan was despite there were ministerial guidelines of standardized content of a spatial plan. Rather than outlining a normative spatial plan from the perspective of academics, we developed strategic points where the local government of Mappi could utilize those as starting point to integrate various competing interests in land utilization in the region. We outlined several approaches that allowed local government to analyze their regional endowment (including their natural resources) and create economic valuations to measure possible impacts from these endowments.

Moreover, we also noted that Mappi still experienced constraints regarding its development outcome as measured through the following macroeconomic indicators: economic growth, poverty rate, and human development index. Not only a good spatial plan allows the local government to allocate land effectively and efficiently, but it can also be used 
as an instrument for economic investment in the region. However, an investment plan not carefully well-thought would lead to environmental degradation and an increasing rate of deforestation in Mappi. Before presenting our ideas and findings of evaluating the regional spatial plan of Mappi, we concluded that specific valuation mechanisms regarding the utilization of land and natural resources should also be presented to the local stakeholders of Mappi and Lestari. We believed such an approach would facilitate more sustainable development of Mappi in the years to come and not rely on the industrialization of the local economy through the capital investment of the heavy manufacturing industry.

Reviewing Mappi's spatial plan in its original form and as a legal binding product (local regulation) illustrated the dynamics of the region's socio-cultural and challenges imposed to the region, something that is easily found in Indonesia. The local government's interest in attracting investment to the region foreshadowed potential conflict of interests among stakeholders and the urgency to reach consensus through negotiation and bargains. Changes in the way government execute their programs based on development and spatial plans were seen as pertinence to accommodate potential investments' requirements on land availability and specific uses of activities. At the same time, there was pressure from environmental groups and central government ministries to the local government to retain the existing tropical rainforest in the region. This in turn put pressure on the local government in balancing economic needs and environmental concerns. Recognizing and reconciling this situation by developing mechanisms to bargain and compromise among stakeholders facilitating better development processes. We posited that our approach to assisting the local government of Mappi in reviewing their spatial plan allows more room for negotiations and compromise, a process that can be replicated by other local governments in Indonesia.

Furthermore, by deconstructing the consultation process of reviewing local government spatial plans from merely informing to building partnership, our approach would minimize potential conflicts that might emerge due to participants' differences in interpreting what the process outcomes would be. Inviting and giving more spaces to local community members to contribute to the decision-making process lead to a better understanding of what each stakeholder's interest is and how each participant navigates their interest and needs in mediating different interests and interpretation of development goals.

\section{RESULT}

The initial evaluation process took place two months before the public hearing that was scheduled in January 2019. Relevant information was sent from a contact person from the local Bappeda (Regional Development Planning Agency) office that facilitated the discussion among experts involved. One major concern raised in the discussion was the urgency to stimulate economic growth while at the same time tropical rainforest (which constitutes almost 75 percent of the total area of Mappi district) can still be conserved. Moreover, despite having $300 \mathrm{~km}$ of coastal lines on its western side, most settlement areas in Mappi are scattered and located in inland areas, which impede the economic development process as those areas can only be reached either through the air or through the river.

The role of the report and written documents were deemed crucial in the analytical process as they provided a glimpse of Mappi's socio-economic structure. Moreover, as communications between experts and local resource persons in Mappi were limited, these reports and documents helped experts visualize stakeholders' perceptions and their interests in formulating development strategies for Mappi. The medium-term development plan stipulates the need for bolstering economic growth through human resources and infrastructure development. This calls for strategic approaches as Mappi currently is part of 122 lagging regions in Indonesia. Contents of Mappi first mediumterm development plan describe the urgency for increasing the quality of life through regional and sectoral development facilitated by:

1. Infrastructure development to increase regional and local connectivity;

2. Education sector development;

3. Health sector development, and

4. Local economic development

As such, the abovementioned statement became the rallying point for the local government to devise development strategies focused on human resources development and infrastructure development. Infrastructure development was envisaged as a means to create connectivity to adjacent districts (notably Boven Digoel Regency and Merauke Regency). However, these goals appeared to be impeded by local government fiscal capacity. After seceded from Merauke, Mappi's local government recorded an average of IDR 0.7 billion per year with its fiscal autonomy degree (Indonesian: derajat otonomi fiskal/DOF) at 1.75 percent between 2007 and 2011 (RPJMD Mappi Regency 2012-2017). This indicated the local government's dependency on the central government's intergovernmental transfer fund policy that accounted for more than $2 / 3$ of the local budget. 
The local government's reliance on central government fiscal policy made any capital investment project seemed unrealistic which in turn dragged the economic growth of the region.

Regardless, as tropical rainforest made up almost 75 percent of Mappi's total area, it has allowed the region to garner additional revenue through revenuesharing funds. Moreover, as Mappi is a part of Papua Province, the region is eligible to receive a special autonomy fund. This fund was initiated during Abdulrahman Wahid's presidency and signed as a law when Megawati Soekarnopoetri took the mantle of presidency in 2001. The special autonomy fund was established to stimulate the economy of the Papua region leading to the local community's increasing prosperity. Under the umbrella of Law Number $21 / 2001$ concerning the allocation of special autonomy funds to Papua Province (and later amended to Papua and West Papua Provinces), both provinces are entitled to receive a larger proportion of revenues (compared to other regions not covered by special autonomy). This approach was set to expire in 2021 (20 years after its initiation). However, based on Mappi's first RPJMD (regional medium-term development plan), it appeared that the local government had already recognized this issue and embarked on a challenging avenue to establish new sources of revenue to replace intergovernmental transfer fund.

Technical report of the regional spatial plan of Mappi was developed in 2010-2011 and consisted of the following elements: a spatial concept that outlined the vision of what Mappi Regency would look like after the plan was implemented for twenty years, the spatial structure and spatial pattern that designated specific functions embedded in certain land allocations and connectivity (represented by networks of infrastructure) among urban settlements, and indicative programs to spur the realization of such vision and spatial design of the region. It outlined what steps needed to be done and broken down programs and projects into several development phases and activities.

An assessment of the regional spatial plan was conducted by comparing the content of the report with both regional medium-term development plans (RPJMD 2012-2017 and RPJMD 2017-2022).
Furthermore, since the central government mandated that the development of regional spatial plan referred to provincial spatial plan, the community service team also explored whether ideas and concepts developed in the provincial spatial plan were adopted and modified according to local needs. We found that the content of the regional spatial planning of the Mappi Regency did not entirely adopt provincial spatial planning. This suggested that the development process of the plan was influenced more by technocratic processes rather than political negotiations. Through an evaluation of the content of the plan also, we revealed a lack of influence of the regional long-term development plan on Mappi's regional spatial plan. While the regulation did not stipulate that the development of regional spatial plans should be aligned with a regional longterm development plan, the alignment between the two would theoretically provide the necessary framework needed for the region to address various development issues through specific land utilization.

The regional spatial plan of the Mappi Regency did not outline clear steps to respond to specific issues already stated in the regional medium-term development plan. This was the result of the detachment of the regional spatial plan-making process with the politically messier process of the sectoral plan such as the medium-term development plan. The central government through the Ministry of Home Affairs already established rigid steps to develop a regional medium-term development plan (RPJMD) and sectoral strategic plan (Indonesian: Renstra dinas), and local governments must comply with those regulations. Moreover, compliance with the MoHA's rules is a must as it jointly controls the local government budget with the Ministry of Finance $(\mathrm{MoF})$. Because of this, most of the indicative programs in the regional spatial plan of the Mappi Regency did not conform to the list of programs and projects outlined in RPJMD and Renstra dinas.

Mappi Regency is also one of 122 lagging regions in Indonesia. This means that the region is underperformed in three macro-economic indicators (economic growth, poverty rate, and human development index) as compared to the national average of those three. Even when compared with neighboring regions such as Merauke Regency, Boven Digoel Regency, and Asmat Regency.

Table 1. Indicators of development outcome (BPS-based HDI data and local annual budget from Directorate General of CentralLocal Fiscal Balance, Ministry of Finance)

\begin{tabular}{lcccrrr}
\hline & \multirow{2}{*}{$\begin{array}{c}\text { Economic growth } \\
(\%)\end{array}$} & $\begin{array}{c}\text { Poverty rate }(\% \text { of } \\
\text { the total }\end{array}$ & \multicolumn{4}{c}{ Human Development Index (HDI) } \\
\cline { 5 - 7 } & & population) & Life Expectancy & Education & GRDP per \\
Mappi & $\mathbf{7 . 3 2}$ & $\mathbf{2 5 . 7 5}$ & $\mathbf{6 4 . 3 0}$ & $\mathbf{6 . 1 0}$ & $\mathbf{1 0 . 4 8}$ & $\mathbf{6 , 1 4 3}$ \\
Boven Digoel & 4.26 & 19.90 & 58.77 & 8.08 & 10.98 & 8,048 \\
Merauke & 7.46 & 10.81 & 66.56 & 8.27 & 12.98 & 10,277 \\
Asmat & 5.83 & 27.16 & 56.32 & 4.71 & 8.12 & 5,771
\end{tabular}

117 WwW.jurnal.ugm.ac.id/jpkm 


\begin{tabular}{llllrrr}
\hline & & & & & \\
Papua Province & 5.35 & 27.62 & 64.28 & 5.56 & 9.68 & 6,543 \\
\hline National Average & 5.07 & 10.64 & 68.32 & 9.46 & 12.39 & 9,111 \\
\hline
\end{tabular}

Table 1 shows the difficulty and challenges of the local government of Mappi in responding to its current development outcome. Despite continuous support from the central government through its intergovernmental transfer fund, particularly the special autonomy fund, poverty was still rampant, and except for mean and expected years of schooling, life expectancy and purchasing power in Mappi were still below the provincial average. Although the economic growth was higher as compared to the provincial average, this figure reflected economic structure with the government and government-related activities as the predominant sector that drove the economy of Mappi.

Having analyzed this information, we presented our initial findings to Lestari local officials first as they had more at stake with this process, especially since they wanted their indicators to be incorporated in the regional spatial planning of Mappi. We argued that as there were many impediments to the development of Mappi, crucial steps needed to be taken. We proposed to alter the development process of regional spatial planning by incorporating economic valuation (including shadow price and opportunity cost) of Mappi's regional endowment as it would allow decision-makers to weigh the cost and benefit of taking a specific development strategy and immediate impacts associated with such a strategy. We also discussed whether the vision of the current head of the region (regent/bupati) might result in net economic loss for Mappi and alternative approaches to alter the possibility of having the net economic loss.

We asked Lestari officials and local government officials from the regional development planning office regarding specific issues in Mappi and whether there were any concerns raised by the local community from those issues. A local government official noted after the establishment of Mappi as a new district; the local government along with local stakeholders have discussed the location of local government offices. They envisioned an area where all offices would be located adjacent to each other to ease coordination and the provision of public services to the local communities. However, a shift in local power structure made the plan difficult to implement as the new power holder argued it was the best option for the local community to retain the location of the new district in its current location and bolster the economy of the area through several programs and projects. As a result, prior government investment in developing a government office complex was neglected.
We noted the reluctance of the local government to realize the plan to relocate to the new area even though several buildings had already been built. As the local government shifted its attention to identifying possible regional economic drivers to transform the local economy, we identified several issues in the region as the result of fuzzy spatial concepts embedded in the regional spatial plan. The first one concerns the unclear spatial structure of the region resulted in siting of public facilities disregarding the distribution of local settlement in Mappi. The second issue evolved from the disconnect between a sectoral plan (represented by RPJPD and RPJMD) and a spatial plan. As each plan was developed separately, it was difficult to track which program and/or project in the regional spatial plan contributed to the implementation of the vision and mission outlined in the sectoral plan. Furthermore, aligning sectoral with the spatial plan also revealed local government different approaches when developing those plans. A sectoral plan, particularly a medium-term development plan, was carefully drafted as it contained the head of the regency's vision; as a result, it directly affected the budgeting process (budget appropriation). Conversely, spatial planning only regulated the utilization of land at the regional level, and it could not provide legitimacy to local community members when they sought to get development approval at individual parcels/lots. The third issue stemmed from the way the regional spatial planning was developed, which was oriented towards technocratic approaches as outlined by the Ministry of Agrarian Affairs and Spatial Planning. Such a strategy, while assuring that the output would be standardized across regions, it failed to recognize regional specific problems including local government capacity and civic capacity in the plan-making process.

These three issues provided a context for the researchers to develop a framework that would be presented during a public hearing. This framework would touch upon the following aspects: (1) rapid assessment of various interests which were expected to emerge during the public hearing, allowing the researchers to better capture the mood and expectations of local stakeholders, (2) while the process will continue to utilize technocratic approach to reviewing and evaluating the plan, the researchers would also incorporate several techniques to refine the evaluation output and assist decision-makers in making better decisions regarding land allocation and utilization, and (2) cost-benefit analysis will be introduced during public hearing allowing those who 
attend the meeting to measure the impact of proposed development strategies. This information was relayed to the local government officials and Lestari staff members to get their initial approval and to make the process run smoothly.

Before attending the public hearing, the researchers were asked to meet the head of the Mappi Regency for an informal debrief of the process. The regent expressed his wishes and concerns regarding the economic growth of his region and wondered whether capital investment financed by the private sector and supported by collaboration between central and local government could expedite achieving the development outcome. He pointed out his plan to develop an industrial port as a feasible solution to penetrate his region's backwardness. The chosen site for this plan was an area inside the conserved tropical rainforest in Mappi. The local government noted the possibility of the borrow-to-use permit for forest area scheme as stipulated in the Ministry of Forest Regulation Number P.18/Menhut-II/2011. It allows protected forests for non-forestry development activities such as general mining activities, power plant installations, power transmission, and power distribution activities (among other things). However, a close examination revealed that under this regulation land utilizations such as an industrial estate and a port were not allowed.

The researchers acknowledged the local need for economic development but at the same time realized that the conventional approach through the industrial port development would bring about environmental degradations and deforestations in Mappi. As such, it was pertinent to provide alternative approaches to stimulating the local economy. These approaches should be tailored with the civic and local government capacity to deliver the expected results. For this reason, we developed a new calculation to provide benefits of employing an industrial estate development vis-à-vis a natural resource utilization through cluster development and appropriate technology.

Local government officials, particularly the regional development planning board, were keen to address the urgency for replacing regional regulation concerning the regional spatial planning of Mappi as they considered it inadequate to respond to the current development challenges and problems. The public hearing was used as a forum to obtain local stakeholders' approval in replacing the current plan with the proposed one. Absent from the discussion was how to situate the new plan with strategic approaches to bolster the economy and increase the local communities' welfare but ultimately sacrificing the environment and the communities quality of life. Faced with this challenge, the researchers proposed a mechanism in which the review result would be accompanied by development alternatives, which could provide an avenue for further discussion among local stakeholders. Moreover, the alternatives were seen not as a challenge to the current thinking concerning land allocation and utilization using industrial estate development; rather, they were means to alter the current approach, which might result in environmental degradation.

The public hearing was set as an avenue for exploring local stakeholders' inputs and perceptions concerning possible development strategies to stimulate the local economy. In this case, the presentation of the result of the regional spatial planning review process was treated as a proxy to explore alternative approaches to development. Attending local stakeholders consisted of representatives of technical local offices responsible for implementing the sectoral plan, invited community members including indigenous people, and the local house of representative members. The presentation itself was carried out by local regional development planning office personnel and assisted by Lestari local staff members.

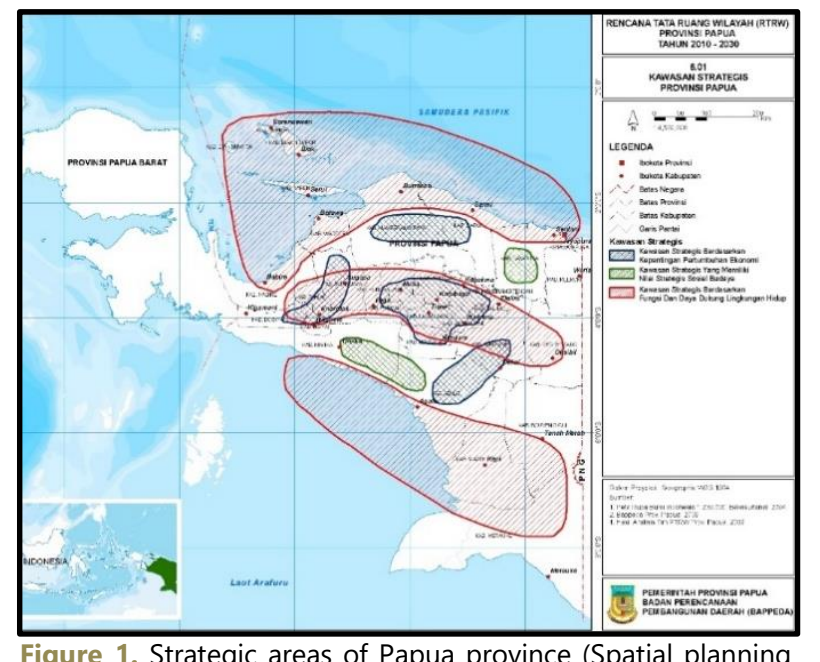
RT/RW of Papua Province 2010-2030)

One important issue raised during the meeting was the ability of spatial planning to attract investments to the region. Many questioned the structure of the spatial plan and wondered whether external pressure, including the establishment of Papua Province's strategic areas as the result of regional spatial planning of Papua Province and the development of Trans Papua, could significantly affect Mappi. Furthermore, several local technical office staff members wondered about the impact of the economic competition between Mappi and its neighboring regions, such as Boven Digoel and Merauke, when there was no clear demarcation regarding regional boundaries among these three neighboring regions. 
To persuade local stakeholders to weigh on alternative approaches to utilizing land - and therefore, lead to significant changes of spatial structure and pattern of Mappi-the researchers outlined the current practice of evaluating regional spatial plans in other places in Indonesia. Economic valuation and accompanying methods were shown as a sample to illustrate to local stakeholders of various possibilities in utilizing natural resources to stimulate the economy without resorting to the practices of industrial estate development. Moreover, drawing from the natural resources balance sheet helped the researchers point out the financial benefits of using agricultural commodities development instead of industrial estate development in Mappi.

Numerous inputs were coming from local stakeholders, ranging from the need to connect the Trans Papua development plan with the existing Mappi infrastructure development plan to the objection of using transmigration policy to increase population in the region. These inputs could be categorized into two major inputs: (1) one concerns the development strategy that the local government of Mappi should consider, and (2) whether environmental concerns, including the conservation and preservation of tropical rainforest, could be integrated into the redesign of regional spatial planning of Mappi.

The result of the public hearing demonstrates the need for planners to master the politics of planning (Benveniste, 1989). Planning as a process requires a planner's technical and political prowess in navigating the dynamics of the decision-making process. Each stakeholder will delineate their input to the process according to their needs and try to influence the outcome of the process (Forester, 1984; Certoma \& Notteboom, 2015). This governs mentality mode implores the ability of structures and procedures of control and disciplining for shaping the mentality of others (Ploger, 2008). As each actor explores the terrain of uncertainty in the decision-making process, they exert the control of their power through access to information and the command of local social and economic resources. As the regent of Mappi pointed out the need for industrial estate development using terms such as job creation and economic growth, local stakeholders situated themselves around these issues and failed to recognize the urgency of preserving tropical rainforest amid the euphoria of economic development.

Environmental issues were brought up by Lestari staff and the researchers during the meeting to address the possibility of using different development strategies in bolstering the economy of Mappi. Their concerns for environmental degradations and lack of government focus on preserving tropical rainforest were amplified in the meeting as local stakeholders expressed hopes for economic growth with the idea of industrial port development. Drawing from similar cases in other regions, the researchers outlined steps to evaluate the financial and economic feasibility of using agricultural commodities instead of industrial estate development. Although this step was accepted by some local government officials, it could not dissuade the government not to develop major projects in the region.

The process of presenting the findings and seeking common ground among the local stakeholders revealed delicate stages of a decision-making process. Actors made compromises and negotiated their positions based on their needs and the benefits they might accrue. While local stakeholders approved the decision to invite investors in Mappi through the industrial port and estate development in the region, they also noted the need to balance the rationale for using such an approach with other mechanisms allowing the economy to grow. The whole process of the regional spatial planning review and public hearing represented the dynamics of the decisionmaking process where issues of regional and local politics overlapped with pressures of economic concerns (Logan \& Molotch, 1987; Benveniste, 1989; Uitermak \& Nichols, 2015; Ozdemir, 2019).

\section{CONCLUSIONS}

In the light of our experience in reviewing the regional spatial planning and public hearing for dissemination and getting consensus from local stakeholders of Mappi Regency, we suggest that planners should be capable of providing alternative narratives as a counterargument for contemporary development approaches. The narrative of bringing in investments from outside the region should be carefully examined and reconsidered. A mere oppositional interpretation of past economic approaches to stimulating development is no longer adequate.

Drawing from the case of the regional spatial plan of Mappi, planners need to rethink and reevaluate their position relative to other actors involved in the decision-making process. Avoiding political interests would allow planners to escape from unforeseen challenges in the future; however, planners would lose their voice in navigating and the ability to influence the development trajectory of the future. Providing alternative development approaches would help community members with less access to economic resources. However, in doing so the planners need to carefully assess community power structures and weigh the optimum strategy to address the development issue. While planners are equipped with 
more knowledge, skills, and capacity to operate than all other actors, they usually navigate their work within the scope of work and less sanguine with their ability to influence the decision-making process. Rarely do planners execute their plan by situating their position as partisans to the issue and provide a stimulating narrative to all involved in the decisionmaking. Despite the possibility of planners becoming vulnerable in the process, it is worth mentioning that they have the capacity for turning resources out (Nichols, 2003).

Planners (or academics turned planners in Indonesia) often choose to relegate themselves as advisors who merely provide technical inputs to decision-makers. This deliberate stance helps planners from backlash from other actors with different perspectives, due to planners' inputs to the process, but it would not help their intent in addressing pressing regional and local development issues. For planners to be reflexive and accountable, they have to aspire to contested ideas rather than to simply optimize the current system where they are in.

\section{ACKNOWLEDGEMENT}

The author wishes to thank Ir. Gunung Radjiman, MSc., Ir. Toekidjo Mulyo Suprapto, MP, and Dr. Yori Herwangi for their comment and inquiries during the reviewing process. Discussion with Lestari local staff (Haditya Pradana and Rintho G. Mathurbongs) provided food for thoughts for instituting certain development approaches to Mappi and possibilities of the local community acceptance, including enthusiasms coming from local government employees and officials in the field.

\section{REFERENCES}

Agranoff, R. (2006). Inside Collaborative Networks: Ten lessons for public managers. Public Administration Review, 66, 56-65. Retrieved from https://www.jstor.org/stable/4096570

Ansell C. \& Gash, A. (2008). Collaborative Governance in Theory and Practice. Journal of Public Administration Research and Theory, 18(4), 543-571. DOI: https://doi.org/10.1093/jopart/mum032

Benveniste, G. (1989). Mastering the Politics of Planning: Crafting credible plans and policies that make a difference (Jossey Bass Public Administration Series). Jossey-Bass.

Bentley, G., Pugalis, L. \& Shutt, J. (2017). Leadership and Systems of Governance: The constraints on the scope for leadership of place-based development in sub-national territories. Regional Studies, 51(2), 194-209. DOI: https://doi.org/10.1080/00343404.2016.118126 1

Brenner, N., Peck, J., \& Theodore, N. (2010). Variegated Neoliberalization Geographies, Modalities, Pathways. Global Networks, 10(2),
182-222. DOI: https://doi.org/10.1111/j.14710374.2009.00277.x

Dowding, K. (2008). Agency and Structure: Interpreting power relationships. Journal of Power, 1(1), 21-36. DOI: https://doi.org/10.1080/17540290801943380

Certoma, C. \& Notteboom, B. (2017). Informal Planning in Transactive Governmentality: Rereading planning practices through Ghent's community gardens. Planning Theory, 16(1), 51-73.

DOI: https://doi.org/10.1177/1473095215598177

Deemer, S. (2009). Using Action Research Methodology to Unite Theory and Practice. Teaching Educational Psychology, 3(3), 1-3. Retrieved from https://files.eric.ed.gov/fulltext/EJ829076.pdf

Emerson, K., Nabatchi, T. \& Balogh, S. (2011). An Integrative Framework for Collaborative Governance. Journal of Public Administration Research and Theory, 22(1), 1-29. DOI: https://doi.org/10.1093/jopart/mur011

Emerson, K. \& Murchie, P. (2010). Collaborative Governance and Climate Change: Opportunities for public administration. In R. O'Leary, D. Van Slyke, \& S. Kim (Eds). 2010. The Future of Public Administration, Public Management, and Public Service Around the World: The Minnowbrook perspective (141-154). Washington, DC: Georgetown University Press.

Forester, J. (1984). Planning in the Face of Power. Berkeley, Los Angeles, London: University of California Press.

Geddes, M. (2010). Building and Contesting Neoliberalism at the Local Level: Reflections on the symposium and on recent experience in Bolivia. International Journal of Urban and Regional Research, 34(1), 163-173. DOI: https://doi.org/10.1111/j.14682427.2010.00955.x

Johnston, E.W., Hicks, D., Nan, N. \& Auer, J.C. (2011). Managing the Inclusion Process in Collaborative Governance. Journal of Public Administration Research and Theory, 21(4): 699-721.

DOI: https://doi.org/10.1093/jopart/muq045

Leck, H. \& Simon, D. (2013). Fostering Multiscalar Collaboration and Co-operation for Effective Governance of Climate Change Adaptation. Urban Studies, 50(6), 1221-1238. DOI: https://doi.org/10.1177/0042098012461675

Nichols, W. (2003). Forging a "New" Organizational Infrastructure for Los Angeles's Progressive Community. International Journal of Urban and Regional Research, 27(4), 881-896. DOI: https://doi.org/10.1111/j.03091317.2003.00489.x

Ozdemir, E. (2019). The Role of the Expert Knowledge in Politicizing Urban Planning Processes: A case from Istanbul. Planning Theory, 18(2), 237-259. DOI: https://doi.org/10.1177/1473095218809747 
Pansardi, P. (2012). Power to and Power Over: Two distinct concept of power? Journal of Political Power, 5(1), 73-89. DOI: https://doi.org/10.1080/2158379X.2012.658278

Peraturan Menteri Kehutanan Republik Indonesia Number P.18/Menhut-II/2011 tentang Pedoman Pinjam Pakai Kawasan Hutan.

Pemerintah Daerah Mappi Regency. (2012). Peraturan Daerah no. 5 tentang Rencana Tata Ruang Wilayah Mappi Regency 2012-2031. Kepi, Mappi: Badan Perencanaan Pembangunan Daerah Mappi Regency.

Pemerintah Daerah Mappi Regency. (2017). Rencana Pembangunan Jangka Menengah Daerah 20172022. Kepi, Mappi: Badan Perencanaan Pembangunan Daerah Kab. Mappi

Pemerintah Daerah Mappi Regency. (2012). Rencana Pembangunan Jangka Menengah Daerah 20122017. Kepi, Mappi: Badan Perencanaan Pembangunan Daerah Kab. Mappi

Ploger, J. (2008). Foucault's Dispositif and the City. Planning Theory, 7(51), 51-70. https://doi.org/10.1177/1473095207085665

Stukas, A.A. \& Dunlap, M.R. (2002). Community Involvement: Theoretical approaches and educational initiatives. Journal of Social Issues, 58(3), 411-427. DOI: https://doi.org/10.1111/1540-4560.00268

Thomson, A.M. \& Perry, J.L. (2006). Collaboration Processes: Inside the black box. Public Administration Review, 66(s1), 20-32. DOI: https://doi.org/10.1111/j.15406210.2006.00663.x

Uitermark, J. \& Nichols, W. (2017). Planning for Social Justice: Strategies, dilemmas, tradeoffs. Planning Theory, 16 (1), 32-50. DOI: https://doi.org/10.1177/1473095215599027

Voorn, B., van Genugten, M. \& van Thiel, S. (2019). Multiple Principals, Multiple Problems: Implications for effective governance and a research agenda for joint service delivery. Public Administration, 97(3), 671-685. DOI: https://doi.org/10.1111/padm.12587

Winter, R. (1993). Action Research, Practice and Theory. Educational Action Research, 1(2), 315-316.

DOI: https://doi.org/10.1080/0965079930010210 